\title{
Library Building Programs: How to Draft Them
}

Mr. Reece is professor emeritus of library service at Columbia University, and has served at several periods on the faculty, of the University of Illinois Library School. In 1950 he was acting head of the Dayton, Ohio, Public Library and Museum while the librarian was abroad.

$\mathrm{T}$ wo forward steps have marked the recent practice of librarians in their work on building projects. One is the formal conferring on mutual problems, exemplified by the activities of groups in the university and public library fields respectively. The other is the preparing of programs, or statements of requirements, setting forth the features desired in contemplated structures.

Both of these steps have seemed overdue. A person need only scan the proceedings of the Cooperative Committee on Library Building Plans to realize how much reason there was for joint attack on the issues facing its members. Essential knowledge could be passed along, experiments reported, and proposals sifted out, with prospect that fewer unfortunate decisions would be built into stone and steel and fewer libraries forced to endure unsuitable quarters. While the task of such groups never can be finished, the reports and the book they already have produced are useful fruit and suggest a pattern for future undertakings.

In the drafting of programs the benefits have been less recognized and the developments so far less conclusive. It is true that their use apparently is becoming established, perhaps because the heads of libraries are accepting a new degree of responsibility for buildings. However, librarians seem not wholly agreed and clear about procedure. Uncertainty and debate have arisen as to how to render statements of requirements most fitting and effective. What should go into them, and how should it be organized and presented? And just what is the part of the librarian in the matter? The present paper deals with these queries, in the hope of clarifying the program-drafter's course. Its sources are the writings, programs and architects listed at its close.

In dealing with statements of requirements it is to be remembered that those for library buildings are only one branch of a large family, that the purposes and the relations of parties in projects of various kinds run parallel, and that what holds for one type is good in principle for all. Little seems to have been said about building programs in general, however, which has not come into the discussions concerning libraries. Librarians apparently have been justified, therefore, in centering attention on their particular sector, and the ensuing treatment follows them in this. At the same time all interested may gain by watching for examples and suggestions in other fields and gleaning what is possible from them.

\section{Some Fundamentals}

Whatever the differences regarding library building programs a few aspects seem generally accepted, beginning with the intention of furnishing the architect the data 
useful as a guide in his work, and thus making more likely the results sought. Almo t everyone recognizes too that programs should be prepared by or with persons knowing intimately the libraries concerned; that they should reflect careful preliminary/ study of needs and conditions; that they ought to embody more or less information about the institutions; and that if they are to be sufficiently definite they must indicate the facilities necessary, with some quantitative clues. Finally, all doubtless would see the advisability of insisting upon practicality, easy and economical operation, adaptability, and allowance for expansion.

So far so good; but the composer of a program is likely to find soon that these points need to be particularized or amplified, and perhaps supplemented by others similarly self-evident. Also, he may meet questions on which they shed no light. In trying to fill the gaps it is simplest to start with the points at agreement.

\section{Benefits to Be Reaped}

First as to the values of a program. Supplying the architect with information means several things, viz., setting forth at the outset the requirements for service, with the conditions and reasons behind them; defining the enterprise in such ways that oversights and misunderstandings can be prevented and the work expedited; exposing the ideas of the owner to the architect, for criticism and mutual understanding; and, if necessary and discreet, fixing the relative importance of the various specifications so that it will be clear what to give up in case there must be sacrifices. Incidental benefits may be that if it is careful and systematic the statement affords the architect a better chance to save time, to do a reasoned job, and to make a profit, and shows possible donors that the project is well thought through. As for effects upon the framers, its development hardly can fail to crystallize their ideas and add to their comprehension of the situation and of the problems entailed.

\section{Putting Needs First}

To realize these values fully librarians are warranted in assuming a free hand in the early stages of their planning. Much may be lost if a program is not shaped originally according to needs and without such limitations as those of funds and site. It may be difficult to hypothecate an ideal situation; and as far as can be judged there are few existing programs which deliberately disregard the restraints mentioned, unless it be where sites are not fixed or restricting and where no figure for expenditures has been set. Obviously one way to forestall the difficulty is to frame and publicize a program before hampering decisions have been made by higher authorities. Subsequently it may be softened by a scale of precedences, as already suggested, so that the total requisitions can be set forth even though their parts must be diversely weighted. Whatever the situation it is only sensible to define the requirements on their merits, rather than according to extraneous factors. Thereafter, if they must compete against other claims they can do so with everything on the table and with a chance to justify themselves. If the aim is adequate planning, any other course seems like too easy yielding.

\section{Those Who Do the Work}

As for authorship, a word will be in order later as to possible joint production by owner and architect. Whether the architect enters thus early or not, a large part of the labor and matter naturally must be supplied by representatives of the institution. The record shows that the work is done variously by the librarian; by a committee or members from corporation or staff, 
or from faculty in case of a college or university; or by the librarian and such a committee in team. Leadership and the bulk of the responsibility commonly lodge with the librarian whatever the machinery, and may be formalized where there is a committee by his membership ex-officio and/or as chairman. Apparently neither librarians nor architects are greatly concerned about the method so long as it accomplishes the job and does so without friction. Doubtless librarians are glad to have it remembered that normally they know the conditions and needs more intimately than do others, and that their insight deserves full credence and utilization.

\section{Preliminary Steps}

Whoever has the task of compiling a building program, the preparatory study necessary is the same. It embraces review of relevant data; scrutiny of the prospective operations and uses; consultation with staff and clientele, and with the librarians and building committees of kindred libraries; and examination of comparable buildings, as the best means of strengthening or correcting ideas already held, and of securing candid reports as to what has succeeded and what has not. Actual programs cite less use of such procedures than might be anticipated, their emphasis being mainly on conferences with committee members, staff and patrons. However, it may be suspected that in gathering material for decisions available resources were drawn upon generally, and that sometimes fairly systematic investigations were made. This would seem especially likely in colleges and universities, where conditions and demands can be gauged with some precision and where it is hardly thinkable that a head librarian or building committee would omit to canvass them thoroughly and to consider the views of the faculty regarding them, whether as part of the functioning of a committee or otherwise. Again, advising with librarians in similar institutions and inspection of other library buildings are known to have been prominent in some cases where such programs fail to mention them.

\section{Light on the Project}

One of the likely products of the study alluded to above is a store of background information. This consists of whatever facts about the library would affect its operations and accordingly call for specific features-notably its aims and policy; its plan of service and functioning, present and future; and, assuming prerequisite decisions have been made, an outline of the organization intended, perhaps in the shape of charts. A resumé of its history alsc sometimes is thought relevant. Presumably the more complete such matter can be in a program, without extending to undure length, the better. Architects again and again say it is useful and can not be too full; and librarians as a rule give it space, even though this is not always large. Aside from the orientation and explanations it provides, it makes possible an understanding of a situation not gainable from a sheer recital of needed particulars, since similar facilities may serve in different ways in different libraries, and therefore may not in themselves indicate too definitely what is sought by them. There of course is no claim that presentation of underlying facts can obviate that independent enquiry and thought through which some architects like to round out their knowledge and thus raise the chances of achieving over-all harmony and usefulness in their buildings. Still less can it take the place of such discussions as may best transmit the "librarian's enthusiasm for his institution and its background and its ... methods." ${ }^{1}$

${ }^{1}$ Letter of September 26, 1951 from Mr. H. Abbott Lawrence, of Lawrence, Tucker and Wallman, Portland, Ore. 


\section{Functions and Parts}

From the general background material just referred to may come definitions of particular responsibilities and activities, and then of the units of organization and work they indicate. Incidentally, the processes preceding formulation of the program should follow this order, otherwise conventional departments and rooms may be assumed without considering whether they accord with the library's objectives and duties and should have a place in the new quarters. The definitions afford the breakdown desirable for initial thinking about the plan, and explain such estimates of capacities as usually accompany them. Instances occur in which departmental capacity specifications are offered without allusion to the business to be performed, but such requests are apt to lack conviction.

\section{Serviceability}

The urgency of making buildings simple, practical and economical often permeates building programs, especially in application to spaces, the relation and placing of parts, and lines of communication and transportation where these are considered. More pointed insistence on such necessities, however, might help to drive home their importance. They merit the same emphasis commonly given to the kindred principles of flexibility and expandability. In most cases the authors of programs wish the way left open and easy for rearrangements, sometimes through unit construction but not necessarily so, and make that desire clear in their statements. The possibility of adding capacities likewise is paramount, although if it is not so generally pressed this may be because so often locations already provide for the space which is its major requisite.

\section{Cost and Site}

Besides the more or less axiomatic points thus far treated there are several less commonly mentioned which doubtless would command equally wide agreement. If feasible without prejudice to the thinking about requirements it should be useful to tell what funds are in prospect. Often there is no reference to these. whether because the facts are unknown or indefinite, or through anxiety not to be fettered by them. Such figures seem to be desired by architects, however, who naturally wish to know the proposed limits of expenditure, and likewise whether construction alone or other items as well are to be covered within them. Then too they might make a program look more complete and intelligent, providing any discrepancies between demands and costs were explained.

Similarly, if an architect is to understand a project he may have to know something about its location. Recommendations on site accordingly are important where it is not settled, and a description may be helpful if a choice has been made. Such matter frequently is missing from programs, however. While this may be because so often locations are predetermined and familiar it can be a loss, especially as concerns exposures. The placing of an edifice in relation to external traffic lines and to points of the compass is likely to affect vitally the access to it, its interior arrangement, and its supply of daylight. Proposals covering this hence may be important, whether in selecting a location or deciding how to use it. So far as they reflect urgent requirements, librarians hardly can afford to neglect them in their statements.

Lines of movement, communication and transportation, or what architects call circulation, also seem worthy of more express treatment than generally they have received. It likely is true that ideas respecting them are interwoven widely with prescriptions as to the relations and situations of parts. They influence compactness and efficiency so 
closely, however, and account for so large - a fraction of the tare, that a librarian may slight part of his problem unless he recognizes and stresses their needs.

\section{Furnishings for the Structure}

The directions in a program regarding equipment and furniture apparently do not have to be extensive. There doubtless should be indication of the pieces suited to carry out the purposes of the building and of the departments and rooms planned, to guide the architect in any decisions he has to make on dimensions. Detailed inventories and layouts seem not essential, however, assuming that the assignments of space desired can be secured without them. Such compilations are requisite later, of course, for reference in drawing up specifications for equipment by whoever bears that responsibility. On these matters a librarian is entitled to remember that he is more nearly an authority than he can be on some aspects and components of a building, especially since much of the furniture is peculiar to libraries in its qualities and application.

\section{Beauty vs. Use}

Esthetic quality receives mention in a few library programs. although usually in a somewhat negative way. The treatments suggest that the authors feared to be thought unduly utilitarian, yet realized that artistic effects belong in the domain of the architect. At any rate they mainly urge such beauty as inheres in simplicity, harmony and dignity, and contributes to effective functioning and an inviting atmosphere, and stop there. Perhaps such guarded advocacy veils a fear of reverting to monumentality, but while such an attitude is comprehensible, librarians might gain by giving it a more positive turn.

As addendum to what without much question should be in a building program, a note is in order as to what definitely ought to be out, viz., features and proposals not adequately authorized. Covering these an architect very pertinently has stressed the need for clearing programs in detail with governing bodies, to make sure that implied requirements involving "costs, site and other controlling considerations" are wholly approved, in order to forestall later "disappointment and waste of time." 2

\section{Approach to Controversy}

So much for matters which raise no sharp issues. There are others on which librarians' opinions or practices vary and about which there appear enough uncertainties otherwise to suggest going into their pros and cons. A few of these bear closely upon the designer's province and task, hence prompted the effort in preparation for the present article to secure viewpoints from a group of architects. Most of the professional men approached had had to do with library buildings, and so were presumed able to furnish significant responses. Naturally they do not agree completely; but most of their advice is pertinent, especially since rules suited to all situations are neither to be expected nor desirable.

\section{Areas and Dimensions}

The first of the mooted questions stems from the specifying of capacities for departments and rooms, which has been alluded to above as a normal feature of a program and which proves in most cases to be welcomed by architects. Shall there be added calculations of the square and/or cubic footage necessary, with stipulations as to dimensions? In some cases librarians seem satisfied with statements of capacities, perhaps supplemented by such quantitative norms as the number of square feet required per reader, to help in translating the estimates into usable space figures. Commonly,

2 Letter of October II, 195I from Mr. John C. B. Moore, of Moore and Hutchins, New York, N.Y. 
however, they favor showing areas and volume and act accordingly, although sometimes only where the reckonings relate definitely to operation, and for functional divisions rather than for particular rooms and comparable parts. Some would go further and propose dimensions, at least where effective performance is at stake.

Architects differ on the point; and it could be inferred that some do not attribute much importance to it, perhaps anticipating that the information they need will soon develop or be amended in conference, whatever clues as to sizes get into the program. In a few instances they seem to consider mere capacities sufficient, and in contrast one holds that areas and dimensions both are needful; but the majority wish requisite capacities and appropriate areas-a "space budget," as one put it-or these plus suggested measurements and shapes. Their preference is made subject often to the condition that specific figures, when offered, should seek to convey approximate ideas and be open to adaptation, "in the spirit of willing compromise-of 'give and take.", They would avoid such rigid prescription as might interfere with the process of composition. Considerable latitude thus is open to the program-drafter, so long as he provides data that will suffice and yet will neither confuse nor bind the designer.

\section{Placing of Parts}

Again, in treating the sections of a building should the framer of a program go beyond indicating the desired relations of parts-a process which generally seems taken for granted-and detail their positioning? Librarians lean to more or less designating of locations, although in practice they are likely to do it department by department, and with a view to getting these put on appropriate floors, rather than through

' Letter of September 25, $195 \mathrm{I}$ from Mr. H. Sage Goodwin, of Schultz and Goodwin, Hartford, Conn. a complete building layout. Architects on the other hand appear pretty much agreed that clear exposition of furictional relations, perhaps with charts showing the connections and the flow of work and traffic among the elements, is the greatest aid toward devising a suitable physical arrangement. Anything more implies attempting what the designer is best fitted to do; besides which it may discourage discussion and the attendant clarifying and evolving of a solution, and perhaps cause a plan to jell prematurely. One respondent goes so far as to say that "if you find an architect who is willing to take the librarian's direction as to the location of the various parts and not their relation, then you have a draftsman, and you are not getting the best out of the architect." 4 Direction, it may be noted, is too muchnot relevant facts and opinions. Some point out that beneficial processes and results need not be endangered and that definite ideas on the positioning of components may be helpful, if they are shown to rest on operational plans and if they are made in general terms and as suggestions to be considered for and against in later conference.

\section{Sketches, or Text Only?}

When positions are to be shown one way to do it is to introduce sketches, and regarding these there is marked difference of view both among librarians and architects. Of the two groups architects have been the more assertive, which is not strange considering that drawings are for them a chief means of expression and the making of plans one of the techniques included in their training. At the same time librarians have been prone to put their ideas into sketch form as well as into words, perhaps even before the day when John Shaw Billings outlined on the back of a discarded envelope a floor arrangement for the central

${ }^{4}$ Letter of October 31,1951 from Mr. Louis E. Jallade, New York, N.Y. 
building of the New York Public Library.

In favor of sketches in programs librarians claim that they may carry what words could not transmit, especially to an architect who is unacquainted with library practice; further, that they may be more stimulating to a designer's imagination than verbal presentation, and that they may save him time and money. Some aver that they need not involve such detail as to be beyond the powers of a librarian to produce, suggesting that if incongruities show up these can be corrected by the architect. According to that belief, too, work on drawings helps to give a librarian an appreciation of the designer's problems. Architects strengthen the argument by saying not only that sketches conform to their manner of thinking and are effective in conveying general concepts and as incentive, but that they sometimes tell more about the librarian's view than many words, aiding for one thing his understanding of "the way in which the librarian would like to operate." One adds: "Sketches as suggestions . . . are extremely valuable not only in passing on the experience of the librarian, but even in stimulating the architect to see if he can make a better one. Interchange of ideas often results in something better than previously was thought of by either."

There are plenty who do not concur. The disclaimers from architects are that sketches may stifle their freedom of thought and criticism and deaden their inventive faculties, whereas a verbal statement challenges their mental resources; and that if they are impeded in the tasks for which they are especially equipped, the client fails to get the grade of service he should enjoy. Hence it is doubtful, states a member of their group, that "sketches are a proper part of a formal program except where they are

${ }^{5}$ Letter of September 26, 195 I from Mr. W. H. Kilham, Jr. of R. B. O'Connor and W. H. Kilham, Jr., New York, N.Y. the only means of showing a relationship."

Psychological factors may play a part here, including the possible reluctance of an architect to pick flaws in a scheme which has become fixed in its proposer's mind, even though he feels that it oversteps bounds and has been built up to undue importance. Again, one of that calling puts much in few words by urging that the architect have opportunity to reach his solution "without the prejudicial influence of a sketch."

Librarians who are on this side of the fence recognize the imprudence of invading the architect's field. Further, they insist not only that laymen are unfitted to draft plans, but that such efforts tend to reflect traditional rather than original ideas. Whether or not because of such reasoning, sketches seldom appear in available programs.

Since both of the above viewpoints are positive and credible, the program-drafter supposedly will be wise to choose between them in the light of his own conditions. Much could depend on his own skill, with the pencil and with the written and spoken word; and on his willingness to have an architect treat any drawing he might prepare merely as a tentative semblance of the way spaces might be arranged, and "push it around." ${ }^{8}$ He might feel freer too if he was disposed to offer variants, as one designer suggested, all to be taken as experimental and subject to comparison and rejection in the interest of the best solution. If an architect already has been designated still more might hinge on his particular feeling about sketches, if that could be ascertained without adverse consequences. In any event what the librarian needs to remember is to keep to his part of the job

' Letter of September 27, 1951 from Professor Talbot F. Hamlin, School of Architecture, Columbia University, New York, N.Y.

T Smith, H. D. "What the Architect Expects of the Client." American School and University, 1949-50, p. $39-42$ (4I).

8 Letter of September 26, $195 \mathrm{I}$ from Mr. Lawrence. 
and to discharge that in the most effectual and considerate manner he can.

\section{Technical Aspects of Buildings}

The debatable matters touched so far lie close to the librarian's field of expertness and intimate knowledge. What of those in which he is not a specialist, but on which he nevertheless may hold legitimate preferences and even supply apposite advice? That is, how far should his program refer to architectural style, design, building materials, decoration, general equipment, furnishings, floor coverings, air treatment, lighting and noise control?

This question is one largely for architects to answer; and among them are men who feel strongly that to treat the subjects concerned even tentatively in an owner's program may set the minds of the parties too early and thus hinder the reconciliations called for by the problem as a whole. One says in this relation, "It is very hard to make ... development [of the project] a success if specific recommendations are made before the client has had the opportunity of seeing his plan grow with the architect." 9 There is alleged to be danger too that secondary considerations will be exalted above utility. All of this perhaps is especially true in reference to style.

In contrast, some endorse expressions on the matters listed, particularly where they bear upon administrative requirements or "have a definite relation to library operation and use." 10 "It is essential," the argument runs, "if for no other reason than that an issue is presented, a discussion follows, and a conclusion is reached through understanding of costs, maintenance, criteria of comfort, and the other factors." 11 And insofar as the subjects concerned are dispu-

${ }^{2}$ Letter of September 26, 1951 from Mr. Kilham. 10 Letter of October 25, I951 from Mr. Henry R. Shepley, of Coolidge, Shepley, Bullfinch and Abbott, Boston, Mass.

${ }^{11}$ Letter of September 26 , 1951 from Mr. Lawrence. table, it aids by bringing them to attention and prompting their consideration in good time, and before decisions have been made which it would be costly to alter.

Specifically, the voicing of opinions on technical topics may enable the architect to show why certain proposals are meritorious and others are not, and clear the way for the owner's wishes where they are appropriate, in pursuance of his "duty ... to plan a building incorporating as many ideas of the client as are practical and possible." ${ }^{12}$ It also may help the architect to "visualize the sort of building desired," restrain him from going to extremes, and facilitate consideration of preferences throughout the planning process and in the interest of harmony in the "over-all picture." One respondent furnishes a reminder too that occasionally a stipulation on the matters concerned needs to be presented clearly and in mandatory form because an endowment or some comparable arrangement depends upon it. ${ }^{13}$

Those architects who welcome preferences on technical matters of course feel nevertheless that their own opinions should "have considerable weight." Further, they join others in stressing that the librarian's desires may well be presented later and in a different way. In this connection one suggests that what goes into a statement of requirements be of a general nature, with more specific advices to come subsequently. Others urge full conference, where a plan may be worked out and the style and related topics developed in collaboration between themselves and the library authorities; and where "the sympathetic architect will be able either to adopt the suggestions where they fit in or to explain to the client why some of the preferences perhaps contradict other parts of the program or violate vital

${ }^{12}$ Letter of September 17, 1951 from Mr. Karl B. Hoke, of Toledo, Ohio.

13 Letter of October 8, r 95 I from Mr. H. D. Smith, University Architect, The Ohio State University, Columbus, Ohio. 
economy or lead to illogical results." 14

In general librarians seem restrained in treating style, materials and the cognate topics, being content usually to tell what the requirements are and what qualities and effects are desired. Indeed, in view of what architects have said they might be more explicit, at the suitable time and with realization that the main thing is the result, and that this can be achieved best by leaving the means to the specialist.

\section{Multiple Proposals?}

In his specifying the composer of a program may ask himself how catagorical it is wise to be. Shall he stick to single-barreled directives, or shall he advance alternatives? While anxious to get at what is in the minds of clients, architects in general naturally are eager for whatever options may enhance their leeway and give rein to their own thinking, and doubtless would wish to introduce them whether or not any came from the owner. One says, "a single recommendation does not lend much to the imagination," and advocates getting numerous suggestions and then using the opportunity "to evaluate them and pick out the ones that you think answer your problem." ${ }^{15}$ Another comments that in an atmosphere of discussion "it is possible to make all kinds of suggestions and eliminate those which seem to be developing illogically." 16

The case for variant proposals is that "the architect lives in a world of alternatives," 17 and that if they are offered-perhaps ranked for relative desirability-they may add to his comprehension of conditions, broaden the discussion of the issues posed, render it easier to avoid premature decisions, and lead to a solution which would not have found favor at first but may turn out to be preferred. Also, where quantities are involved

14 Letter of September 27, 1951 from Professor Hamlin. 15 Letter of Uetober 31 , 1951 from Mr. Jallade.

16 Letter of October 30, 1951 from Mr. Ralph Walker, of Voorhees, Walker, Foley and Smith, New York, N.Y.

${ }_{17}$ Letter of September 26, 1951 from Mr. Lawrence. optional figures may help to reveal the minimum which will suffice-information possibly obscure otherwise. Such benefits do not prove that any alternatives forthcoming need have place in a program. If they can be offered that early, however, readjustments may less likely be necessary later and when changes have become expensive. Everything is put into the picture, for consideration at the suitable time, and decisions still can be postponed so far as that is advantageous. Whenever broached, the choices of course should not be inconsistent with each other in purpose, lest they be confusing rather than helpful to one who is not a librarian.

Despite the above, the programs examined concentrate as a rule on single and unqualified specifications. One librarian advocates this on the ground that a flatfooted directive spurs healthy debate. However general that aim, the process of thinking through their enterprises must often have led composers to firm opinions, and to focusing on such conclusions as a means of impressing readers and fortifying their case. They even may have thought of the requirements they arrived at as scarcely subject to discussion; or if they felt uncertainty, feared nothing would be gained by betraying it.

Probably with all their earnestness, however, the compilers of programs have not meant to be exigent, realizing that they are not infallible, that an architect can be a helpful partner, and that adaptation is inevitable. They may have hoped to invoke in their negotiations the qualities once attributed to a New York state governor, of being "firm, moderate, ... conciliatory in non-essentials, unwavering in matters of principle." With that attitude, and assuming they included some proposals of which they would not make an issue, they normally might count on respecting the architects' interest and at the same time attaining their chief objectives. 


\section{Cooperative Programs}

Some readers of this paper may be wondering whether building programs need be framed by owners alone, and whether in the case of libraries some of the questions so far discussed would not vanish if they were prepared jointly with architects. Such collaboration should be possible, and might save time and eliminate or reduce points of disagreement. That it would find considerable favor with architects can be gathered from the emphasis some of them place on close and continued consultation supplementing a program. One endorses it in the following words: "the making of a program is a definite creative act and should be a part of the process of design. Ideally, the program should be the joint and cooperative effort of the architect and the client working together in the fullest mutual confidence. For this reason it is most advantageous to all parties concerned to have the architect chosen work along with the authorities who prepare the final formal program of a building in advance of its actual issuance. This does not mean that the good architect wishes in any way to impose upon the client's ideas in opposition to the client's interests or desires; it is only by having the advice of an architect during the process of program-making that the individual or committee concerned will be able to save itself from many points of confusion and from a program which may unconsciously contain mutually exclusive elements." 18

This is a strong plea, and librarians hardly can deny it credence. However, a librarian or committee certainly needs to have threshed out its problem before going into conference, and this effort naturally would produce some kind of a program, even if not a final and written one. Also, one librarian has suggested that the state-

18 Letter of September 27, 1951 from Professor Hamlin.

JULY, 1952 ment of requirements should be shaped up before an architect is designated, since situations may arise in which it ought to influence that selection. There furthermore is a warning against too early association in the comment that "the architect is by training persuasive and as a collaborator is likely to talk the librarian out of ideas which are important and which should be preserved for discussion at a more concrete stage." ${ }^{19}$

These lines of reasoning may beg the question in part, yet can carry a good deal of force. In some instances librarians might have ground to fear premature and unnecessary compromise. In others there might be simple anxiety that full weight be accorded their views, as those of the parties who know the needs and what is requisite to meet them, and who are responsible for ultimate success or failure. Frustration certainly is in the offing where an ill-adapted scheme for a building, and with it perhaps an unsuitable plan of work for the library itself, is forced upon institutional officers, as might happen if the joint effort was dominated by persons having no concern in eventual operation. Representatives of libraries seem to realize this, for they show by expression and action that they prefer to keep the drafting of programs in their own hands.

With all their desire to work alone at the start, librarians still may be ready and glad to have an architect shape up a program based on his own study of conditions, hoping that he thus can contribute to a better consummation than cooperative work throughout could produce. Neither they nor architects suggest, however, that the latter should prepare programs except by way of defining the approach as they see it. One architect has stated that a member of his calling, unless in unusual circumstances,

19 Burchard, J. E. et al. Planning t'te University Library Building. Princeton, Princeton University Press, 1949, p. 122. 
"could not possibly write a program for a library ... the librarian is the only one that knows what is required," ${ }^{20}$ and another that an architect does not have his problem until the program has been "completely developed by an expert," ${ }^{21}$ meaning the librarian.

\section{Is a Program a "Must"?}

Again with thought of the issues they raise, how indispensable are programs? Confirming the values cited earlier, architects generally say or imply that such statements have an unquestionable place, at least as a basis for dealings between themselves and owners. For example, one declares that if "clear and intelligent" they can be most helpful guides, and another says they are essential if the architect is not to go wrong at the start. Then too their use is spreading, which must mean something, even though it seems confined largely to college and university libraries.

On the other hand the programs that can be gathered so far are few as compared with the buildings constructed, hence they hardly can be the sole means of accomplishing their task. Presumably adequate conferring can remove much or all of the occasion for written statements, especially in case of small and simple structures. Architects again and again stress the importance of close and constant consultation with clients, from early stages on. This they regard as imperative even with the best of formal memoranda-something in fact which no amount of "programming" can replace, and which probably they would give first rank if there had to be a choice. The summation may be that while it is desirable for librarians to count on compiling statements of requirements as a normal step, they should recognize that the business

${ }^{20}$ Githens, A. M. "The Architect and the Library Building," in Fussler, H. H. Library Buildings for Library Service. Chicago, University of Chicago Press, 1947, p. 94-106 (p. roo).

${ }_{21}$ Jallade, L. E. "Are You Prepared to Plan a New Building?"' Library Journal 69: 1077-79 (p. 1078), Dec. I5, 1944 . of getting their ideas across does not depend wholly on that, nor end with it.

\section{Open Secrets}

There remain for notice a few tricks of the program-drafter's trade, of a sort which are elementary but might be overlooked. For instance, the citing of examples from other buildings may gain readier consideration for a librarian's suggestions, whether because the features concerned have proved successful or because of respect for precedent. It is not known why so few available statements of requirements employ such illustrations; but if they were pertinent and their authors possessed the information for them, it seems a loss that they were not used to strengthen the programs.

Composers of statements also may need to think often of the way readers are going to be impressed. A compiler labors over his draft in the mood of playing for keeps. What can he do to invest it with such character and tone and form that it will convince the architect? How build it so that the library's interests will be advanced if it is used to win the approval of the committees, officers and others who hold purse strings or have power to make controlling decisions, as sometimes happens?

The answers to these questions look didactic, yet they are pertinent enough to bear reciting. To a large extent they center in correct, forthright, logical writing. This of course necessitates selectivity and conciseness, so far as they do not hamper adequate presentation; with recognition that the readers who count may expect to get their information in brief time and with little study, and that a statement which has been boiled down is likely to be more comprehensible than a discursive or over-detailed one. It also implies phrasing which, while definite in purport, is free from jargon, understandable to laymen, and suggestive of sophistication and perspective. Finally, 
it means a tone which is clear and assured, yet tactful and forbearing. On the whole existing programs measure up fairly well on these points, the composition and organization being generally creditable and evidences of myopia and provincialism not pronounced.

\section{Division of Labor}

Finally, some of a program-drafter's success in carrying his points may lie in realizing just what his job is and where it ends. Summarizing much that already has been said, he is or he represents one party, and but one, in an undertaking; and his responsibility, while real and inescapable, is only a segment of the whole. On the one hand it is to provide a platform for the work of all the participants in the project, with thought of the architect's views if occasion arises as early as the period for shaping the program, but without being overborne by them. On the other hand it is to avoid imposing even his desiderata upon his associates as unarguable law, to leave the way open for the architect's suggestions, and to keep from trenching upon the province or prerogative of that partner. To adopt phrasing which is becoming encouragingly conventional, the librarian's role is to give the architect the problem and leave to him the solution; to tell him what to build-not how to build it, which is his business. Common sense and modesty and consciousness of their own limitations of course should be enough to keep librarians on their own side of the line in all of this, and happily it seems as a rule to work so. If anything, the framers of library programs appear overly solicitous not to poach upon the preserves of architects.

Even though programs reveal a punctilious attitude toward designers' rights, however, architects apparently have had experience with librarians or other patrons which lead them to emphasize the conditions and demands they face, as explaining the need for accommodation. They wish it clear that often they must be definite in the positions they take. They show concern lest the librarian's zeal to do the best he can for his institution make him forget that the architect is expected to reconcile a variety of requirements, of which the librarian's are only one section, and to produce an integrated building satisfactory to all. As one put it, "The best results will be obtained if the architect is given a free hand to develop a scheme which will be functionally suitable to the needs ... and to the conditions of the site." ${ }^{22}$

Moreover, architects repeatedly point out that the terms and necessities of the problem as a whole take precedence over specific items. Hence the owner's readiness to yield where possible on his stipulations, already shown to be consonant with positiveness at other points, now appears essential to an acceptable over-all solution. Without it an architect may be handicapped in exercising his peculiar skills, i.e., those in "the arrangement of rooms, the study of daylighting and orientation, the economic use of space, the use of materials, the proper application of color, the routine of service," and the like, and thus be hindered in his "duty to weld all these functional factors into a pleasing and attractive building." ${ }^{23}$ All of which is doubly relevant because every undertaking is individual, and has to be approached without preconceptions traceable to previous cases or experience.

This earnestness of architects does not lessen their appreciation of the part librarians can play. Adequate presentation by the latter of administrative needs is desired and "invaluable," not only in a program and otherwise at the outset, but in criticism and suggestions on sketches as the project develops, so that the results will be "workable"

\footnotetext{
${ }^{22}$ Letter of October 5, $195 \mathrm{I}$ from Mr. Arthur H. Eadie, Toronto, Can.
} 
and in accordance with the way the members of a staff plan their activities. By way of standing invitation to such expression one respondent in the enquiry for this paper said, "a state of flux and willingness to change or harbor new ideas is extremely valuable . . this applies to the architect even more than librarian or board members. ${ }^{24}$

\section{The Guiding Rule}

The keys to effective relations therefore are consultation and team-work, with respect by each party for the competence of the other, beginning at whatever stage may be agreed upon-"the librarian advising and informing the architect as to his particular needs, and the architect evaluating these data and placing them on paper for study and review" ${ }^{25}$; the librarian allowing the

2 Letter of September 25, r951 from Mr. Goodwin. architect the necessary leeway in his task, and the architect not attempting "to dictate function and specify allotments." ${ }^{26}$ With such understanding a kind of comradeship can develop, based on united effort in meeting difficulties, seeking lessons in the failures and successes of others, and exploring possible solutions. Narrowed down in application to a building program this viewpoint suggests that it be "the simplest possible statement of the problem, as definite as it can be in all matters dealing with the purpose, function and conditioning of the building, and as free as possible in all matters dealing with plan arrangements and design." ${ }^{27}$

${ }^{25}$ Letter of September 18, $195 \mathrm{I}$ from Mr. Tames Gamble Rogers II, Winter Park, Fla. and New York, N.Y.

${ }_{26}$ Letter of October 2, $195 \mathrm{I}$ from Mr. Truman E. Phillips of Wolff and Phillips, Portland, Ore.

${ }^{27}$ Letter of September 27, I95I from Professor Hamlin.

\section{SOURCES}

1.-Chief books and articles

American Institute of Architects. Library Buildings, 1947 , p. I-20. (Building Type Reference Guide No. 3. A I A File No. D-5) Partially also in Bulletin of the American Institute of Architects $1: 3: 25-43$, July 1947.

Bean, D. E. and Ellsworth, R. E. Modular Planning for College and Small University Libraries. $\quad$ 1948, p. I-4.

Burchard, J. E. "Post-war Library Buildings." College and Research Libraries 7: I 1 8-26, April 1946.

Burchard, J. E. et al., eds. Planning the University Library Building. Princeton, Princeton University Press, 1940, p. 121-26.

Fussler, H. H., ed. Library Buildings for Library Service. Chicago, University of Chicago Press, 1947, p. 22-24, 97-100, I 88-89, 194-96.

Gerould, J. T. The College Library Building. New York, Scribner, c1932, p. 18, 26-27.

Green, B. R. "Planning and Construction of Library Buildings." Library Journal $25: 677-83$, Nov. 1900.
Lyle, G. R. The Administration of the Col. lege Library. New York, Wilson, 1949, p. $540,544-54$.

Randall, W. M. "Some Principles for Library Planning." College and Research Libraries 7:319-25, Oct. 1946.

Randall, W. M. and Goodrich, F. L. D. Principles of College Library Administration. Chicago, ALA and University of Chicago Press, c194I, p. 172-74.

Schunk, R. J. Pointers for Public Library Building Planners. Chicago, ALA, 1945, p. 9-13.

Smith, H. D. "What the Architect Expects of the Client." American School and University, 1949-50, p. 39-42.

Wheeler, J. L. and Githens, A. M. The American Public Library. Building. New York, Scribner, 1941, p. 15-23, 75-81.

Wilson, L. R. and Tauber, M. F. The University Library. Chicago, University of Chicago Press, c1945, p. 460-6r.

\section{2.-Available programs}

Blanchard, J. R. "Preliminary Statement Prepared for the Architect of the College 
of Agriculture Library Building, University of Nebraska." 1950.

"Building Program for Greenville College Library." 1948?

Burchard, J. E. "Program for a New Library Building at the Massachusetts Institute of Technology.” 1945.

Brown, C. M. "Requirements for a Library for the University of Southern California." I930.

California University. Santa Barbara College. "Program for the First Units of a New Library Building." 1950.

Cornell University. New York State College of Agriculture and Home Economics. "Considerations in Planning the Library Building." [1945?]

Goucher College, "Requirements for the Proposed Library at Goucher College, Prepared for Use in a Competition to Select an Architect." ALA Bulletin 34:145-5I, Aug. 1940.

\section{[1946]}

North Carolina. University. Women's College. "Statement of the Requirements for a New Library Building. ..." 1947.

Pennsylvania. University. Library. "Program for the Architects, University of Pennsylvania Library Building." 1949.

Queens College. Library Building Committee. "Proposed Library Building for Queens College, Flushing, N.Y." 1944.

[Sanderson, C. R.] "New Northern Branch ...." [of the Toronto, Canada, Public Libraries]

Virginia. State Library. "Proposed Requirements for a New State Library Building." 1938.
3.-Contributing architects

Mr. C. C. Briggs, of Emerson, Gregg and Briggs, Peoria, Illinois

Mr. Arthur H. Eadie, Toronto, Canada

Mr. H. Sage Goodwin, of Schutz and Goodwin, Hartford, Connecticut

Prof. Talbot F. Hamlin, School of Architecture, Columbia University, New York, New York

Mr. Karl B. Hoke, Toledo, Ohio

Mr. George L. Horner, Superintendent, Physical Plant Department, State University of Iowa, Iowa City, Iowa

Mr. Louis E. Jallade, New York, New York

Mr. Walter H. Kilham, Jr., of R. B. O'Connor and W. H. Kilham, Jr., New York, New York

Mr. Carl Koch, of Carl Koch Associates, Cambridge, Massachusetts

Mr. H. Abbott Lawrence, of Lawrence, Tucker and Wallman, Portland, Oregon

Mr. John C. B. Moore, of Moore and Hutchins, New York, New York

Mr. Truman E. Phillips, of Wolff and Phillips, Portland, Oregon

Mr. James Gamble Rogers II, Winter Park, Florida and New York, New York

Mr. Henry R. Shepley, of Coolidge, Shepley, Bullfinch and Abbott, Boston, Massachusetts

Mr. H. D. Smith, University Architect, The Ohio State University, Columbus, Ohio

Mr. Ernest L. Stouffer, Architect Physical Plant Department, University of Illinois, Urbana, Illinois

Mr. Ralph Walker, of Voorhees, Walker, Foley and Smith, New York, New York

Prof. William Ward Watkin, Dept. of Architecture, The Rice Institute, Houston, Texas

\section{Catalog of the McAlpin Collection}

Union Theological Seminary Library, New York (Robert F. Beach, Librarian) announces the availability, at one-half of the published price, of the 5-volume Catalogue of the McAlpin Collection of British History and Theology. This notable bibliographical work gives full details in line titles, for 15,000 books and tracts on religious and politico-religious controversy printed in England during the 16 th and 17 th centuries. Indexed. Cost is now $\$ 25.00$, with no postage charge on pre-paid orders. 